\title{
The Research on the Influencing Factors of the Farmers' Compensated Withdrawal of Land Contracting Management Right
}

\author{
-Based on Grounded Theory \\ Yingying $\mathrm{He}^{\mathrm{a}}$, Ruiping Ran $^{\mathrm{b}}$ \\ College of Management, Sichuan Agricultural University, 611130 ,Chengdu,China \\ aaisinary@163.com, bruipingran@yahoo.com.cn
}

Keywords: Withdrawal of Contract Management Right; Influencing Factors; Grounded Theory; Farmers' Demand

\begin{abstract}
Through in-depth interviews with 120 farmers who wish to withdraw their land contractual management rights in Chengdu and grounded technical methods to analyze the factors affecting the farmers'endogenous demand and land requisition, the impact of farmers' withdrawal from the contracted land was obtained. There are five factors: physiology, safety, emotion, respect, and self-realization. Among them, the physiological and safety needs are the main factors influencing farmers' decision making, and the emotional and developmental needs are also certain. The degree affects the farmers' decision-making. Based on this, the paper puts forward policy proposals for enriching the content of compensation, establishes a long-term compensation mechanism, and retains other rights and interests of farmers as members of collective economic organizations.
\end{abstract}

\section{Introduction}

The compensated exit policy of land contracting right is another important strategy for deepening rural reform in China. As the main body of this policy, farmers' response and intention directly affect the implementation effect of the policy. Therefore, on the basis of understanding the willingness of farmers to retreat, the research on its influencing factors plays an important role in the improvement of relevant institutions and the implementation of policies. Based on this, the author conducted a survey of 120 households in Chengdu. By the Grounded Theory, the endogenous demand of farmers and the influence factors of withdrawal were analyzed step by step,concluding seven generic factors and four main category factors that affect the farmers' right to quit the contract. This paper summarizes the core influencing factors and provides suggestions for the implementation of the exit policy of land contracting right.

\section{The Characteristic Analysis of the Farmers Willing to Quit the Contracted Management}

Chengdu,as one of the experimental areas of rural reform in Sichuan province, specially formulating special plans for the pilot project on the exit reform of land contract management,has the rich experience and good research foundation. The author took Chengdu area as the scope and randomly selected 200 households, finding that 120 households had the intention to quit the contract. Through in-depth interviews with these farmers,their individual characteristics and family characteristics are understood. (see table 1).

\subsection{Individual characteristics}

There were slightly more men than women, of whom 77 were males, accounting for $64 \%$ of the total; There are 67 people aged between 36 and 50 years old, and 41 people over 51 years old, accounting for 56\% and 34\% respectively; There were 49 students who graduated from primary school, accounting for $41 \%$, and only 10 received college degrees or above; There are a large number of people with multiple identities, and 34 interviewees have the status of village cadres, 
farmers and agricultural professional managers, accounting for $28 \%$ of the total. There are two reasons for this:one reason is that people with these identities have lived in the countryside for a long time, increasing their chances of being interviewed, and the second reason is that these people have a better understanding of the relevant policies on the paid exit of land contract management rights and are more willing to accept the implementation of the new policy.

\subsection{Family characteristics}

There are $97 \%$ of households whose number of families is between one and four people,generally two generations; 91\% of households are mainly engaged in traditional crop production, such as food and vegetables, with low return on investment in agricultural production; $44 \%$ of farm households earn less than half of their total income, showing that more than half of households no longer depend on land for their livelihood.By calculation, the per capita land area of peasant households is relatively small, about $1 \mathrm{mu} /$ person, which is consistent with Chengdu statistics. The contracted land location is good, so among the farmers willing to withdraw from the contracted land, 113 farmers said that the contracted land was located in the plain area, accounting for $94 \%$ and only seven farmers indicated that a small proportion of the household contracted land was located in the hills; In addition, 53\% of farmers said that the contracted land had been transferred to farmers' cooperation in whole or in part, but they were still willing to withdraw part or all of the contracted land as a result of family development.

Table 1 Basic Information of Respondents

\begin{tabular}{|c|c|c|c|}
\hline \multicolumn{2}{|c|}{ individual, family characteristics } & sample size (person) & proportion (\%) \\
\hline \multirow{2}{*}{ gender } & male & 77 & $64 \%$ \\
\hline & female & 43 & $36 \%$ \\
\hline \multirow{4}{*}{ age } & 35 and below & 12 & $10 \%$ \\
\hline & 36 to 50 & 67 & $56 \%$ \\
\hline & 51to65 & 34 & $28 \%$ \\
\hline & $\begin{array}{c}\text { aged more than } 65 \\
\text { years }\end{array}$ & 7 & $6 \%$ \\
\hline \multirow{4}{*}{$\begin{array}{l}\text { the degree of } \\
\text { education }\end{array}$} & primary and below & 49 & $41 \%$ \\
\hline & junior high school & 44 & $37 \%$ \\
\hline & secondary school & 17 & $14 \%$ \\
\hline & $\begin{array}{c}\text { junior college or } \\
\text { above }\end{array}$ & 10 & $8 \%$ \\
\hline both identity & - & 34 & $28 \%$ \\
\hline $\begin{array}{l}\text { quantity of labour } \\
\text { force }\end{array}$ & 1-4 people & 116 & $97 \%$ \\
\hline \multirow{2}{*}{ the main business } & planting & 109 & $91 \%$ \\
\hline & farming & 11 & $9 \%$ \\
\hline $\begin{array}{l}\text { the proportion of } \\
\text { agricultural income }\end{array}$ & Less than $50 \%$ & 53 & $44 \%$ \\
\hline per capita land area & - & $1 \mathrm{mu}$ & - \\
\hline \multirow{2}{*}{ terrain } & plain & 113 & $94 \%$ \\
\hline & hills & 7 & $6 \%$ \\
\hline $\begin{array}{c}\text { The number of } \\
\text { people joining the } \\
\text { cooperative }\end{array}$ & 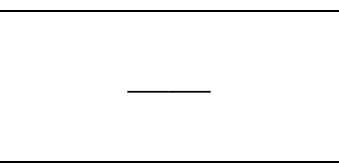 & 64 & $53 \%$ \\
\hline
\end{tabular}




\section{Analysis of the Factors Influencing Farmers' Withdrawal from Contract Management}

Grounded Theory, a special methodology proposed by Glaser and Strauss by analyzing empirical data, is a qualitative research method from the bottom up.Through the three steps of "open login, axis login and selective login", the original data is encoded to make the text data logical and theoretical. Based on the technical method of Grounded Theory, this paper analyzes and induces the main factors that affect the farmers' withdrawal from the land contracting right (see table 2 and figure 1).

Table 2 Main Categories Form Tables

\begin{tabular}{|c|c|c|c|}
\hline & coding initial concept & $\begin{array}{l}\text { category factor and frequency of } \\
\text { occurrence (secondary) }\end{array}$ & $\begin{array}{c}\text { principal } \\
\text { category factor }\end{array}$ \\
\hline 1 & $\begin{array}{l}\text { farm income } \\
\text { compensation }\end{array}$ & \multirow{4}{*}{ economic compensation (120) } & \multirow{4}{*}{$\begin{array}{l}\text { physiological } \\
\text { needs }\end{array}$} \\
\hline 2 & $\begin{array}{l}\text { agricultural } \\
\text { supplementary income } \\
\text { compensation }\end{array}$ & & \\
\hline 3 & living allowances & & \\
\hline 4 & $\begin{array}{l}\text { cooperation income } \\
\text { subsidies }\end{array}$ & & \\
\hline 5 & $\begin{array}{l}\text { whether to keep the } \\
\text { homestead }\end{array}$ & \multirow[t]{2}{*}{ housing security (23) } & \multirow{6}{*}{$\begin{array}{l}\text { security } \\
\text { requirements }\end{array}$} \\
\hline 6 & urban housing problem & & \\
\hline 7 & $\begin{array}{l}\text { whether or not there is } \\
\text { child to support }\end{array}$ & \multirow{4}{*}{ pension security (70) } & \\
\hline 8 & reduced labor capacity & & \\
\hline 9 & $\begin{array}{l}\text { old people's life } \\
\text { security }\end{array}$ & & \\
\hline 10 & $\begin{array}{l}\text { whether to buy social } \\
\text { security }\end{array}$ & & \\
\hline 11 & $\begin{array}{l}\text { the problem of } \\
\text { unemployment }\end{array}$ & unemployment insurance (5) & \multirow{3}{*}{$\begin{array}{l}\text { emotional } \\
\text { needs }\end{array}$} \\
\hline 12 & $\begin{array}{l}\text { preference of ecological } \\
\text { environment }\end{array}$ & \multirow[b]{2}{*}{ emotional compensation (14) } & \\
\hline 13 & $\begin{array}{c}\text { preference of living } \\
\text { environment }\end{array}$ & & \\
\hline 14 & technical training & vocational skills training & \multirow{4}{*}{$\begin{array}{l}\text { development } \\
\text { needs }\end{array}$} \\
\hline 15 & $\begin{array}{l}\text { entrepreneurship } \\
\text { support }\end{array}$ & promotion (10) & \\
\hline 16 & the opportunity cost & \multirow{2}{*}{ family development planning (12) } & \\
\hline 17 & education conditions & & \\
\hline
\end{tabular}

Open Coding. Through open coding, from nearly 6000 original records, we selected 398 original statements whose occurrence frequency is more than five times and the content is clear. In the end, 17 initial concepts were obtained, which affected the farmers' right to quit the land contract and classified them into seven categories: economic compensation, housing security, old-age security, unemployment insurance, emotion, vocational skills training, and family development planning.

(1) Economic compensation refers to the amount of withdrawal compensation. After retiring from the contract land, farmers hope to get compensation for the income of farming land, compensation for agricultural supplemental income and living allowance, and some farmers who join the cooperation hope to get compensation equivalent to the income level of the cooperation; 
(2) Housing guarantee refers to whether the government will issue rent and purchase subsidies, and whether the village collective reserves the right to use the homestead;

(3) Pension security refers to whether the farmers have children to support and whether the government will purchase the endowment insurance for the retired farmers;

(4) Unemployment insurance refers to whether the government still provides unemployment benefits when rural households lose their jobs;

(5) Sentiment refers to the psychological preference of farmers to rural and urban ecology and living environment;

(6) Vocational skills training promotion means that farmers are expected to get reemployment training and entrepreneurial support after they quit the contract management rights;

(7) The family development plan includes the concerns of farmers about the opportunity cost of retirement, the development of the industry and the education of children.

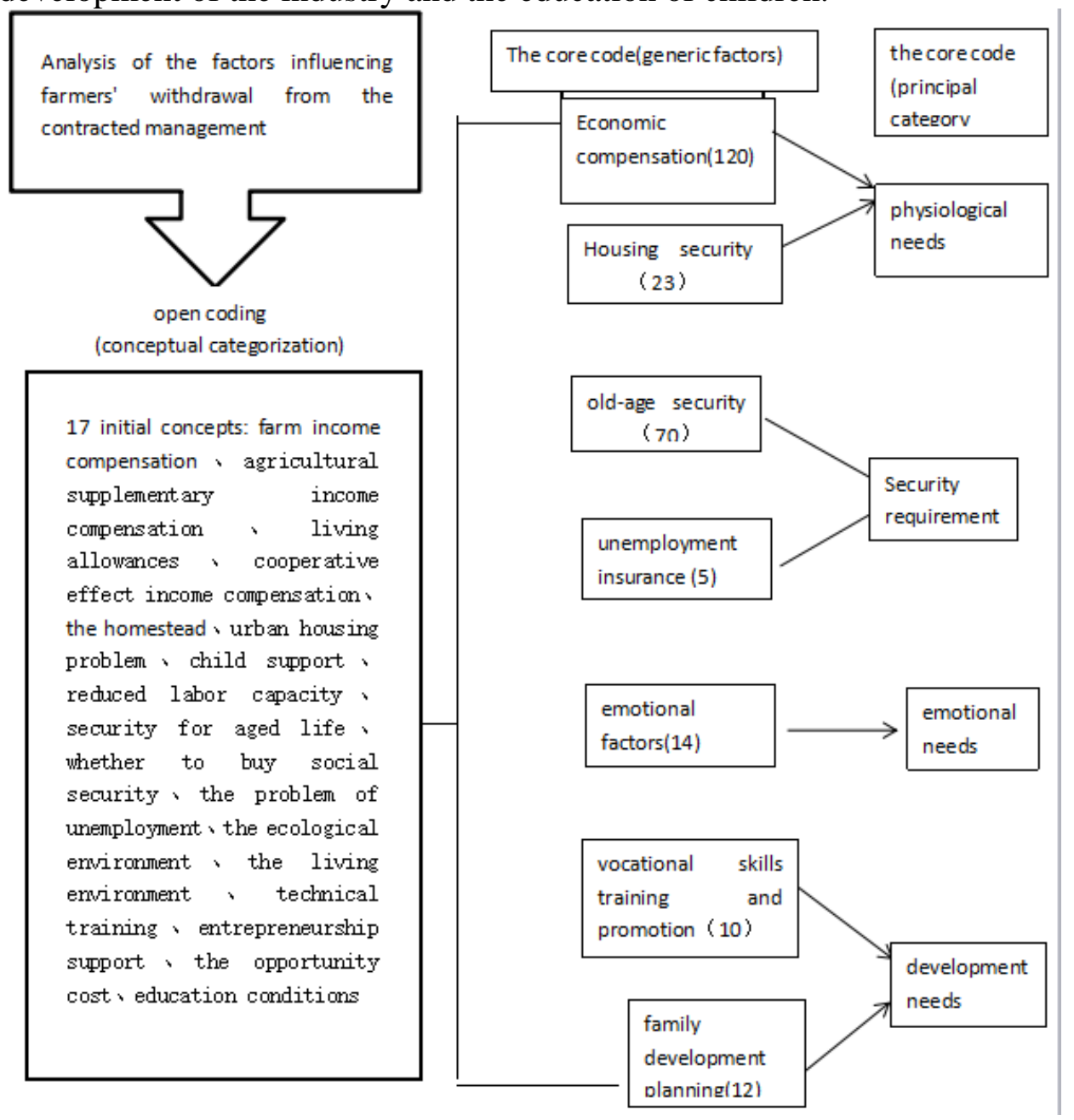

Fig.1 Analysis Frame Diagram of Influencing Factors of Farmers' Withdrawal from Land Contracting Management Right

Axis Coding. On the basis of open coding and through the axial coding, the author integrated the internal relation of the seven categories of factors in the conceptual level, finding that the influence factors of farmers' withdrawal are closely related to their own needs: (1) Land is an important property of farmers, with functions of parenting, so, when choosing whether to withdraw from contracted land, farmers will focus on the how much of compensation as well as the preserve of housing land use right, which is the result of basic needs for food and clothing live line; (2) Land has guarantee function and is the last insurance of farmers' unemployment and old age, so the subsequent social security is also an important factor affecting farmers' decisions, which is rooted in the pursuit of security. (3)The withdrawal of the contracted land means the long-term separation from the original rural life and the original social circle. Therefore, the farmers need to make 
emotional choices. (4) According to the needs of family development, farmers choose between new industries and agricultural industries, which results from the pursuit of social status and self-worth. Based on this, this paper generalizes these seven categories into four main categories: physiological needs, safety requirements, emotional needs and development needs.

Core coding. Through the core coding, it is found that the farmers' withdrawal from right to contracted management is mainly affected by four factors: First, the factors of physiological demand, including the amount of compensation and the guarantee of housing,which are the primary considerations for most farmers; Second, the security demand factor, mainly including the old-age security and unemployment insurance, which is a major concern of the elderly. The third is the emotional demand factor, mainly from the farmers' uncertainty about the unknown life and the attachment to the inherent life circle; Fourth, development demand factors, including vocational skills training, family development planning, children education and other factors. Among them, the first three factors that occur frequently are economic compensation (120 times), pension security (70 times) and housing security (23 times), showing that the majority of farmers are still in the stage of pursuing the satisfaction of physiological needs and safety needs. Therefore, economic compensation and indemnity are the core factors that affect the decision-making of farmers.

\section{Suggestions for Promoting the Implementation of the Policy on the Exit of the Right to the Contracted Management of Land}

Rich Compensation Content. Through the analysis, it is found that the farmers' right to exit the contract is affected by social security, emotion, development and other factors besides economic compensation. But at present, the compensation standard in each experimental area is only a single land compensation. Therefore, it is necessary to change the original single economic compensation mode, take full account of farmers' safety needs, emotional needs and development needs, and integrate social security, pension security and emotional compensation into the compensation scope.

Establishing long - term compensation mechanism

For the security demand of farmers, on the one hand, multiple compensation mode such as "part of the compensation + endowment insurance" and "part of the compensation + village collective fund" are provided to educe the risk of farmers' withdrawal through sustainable compensation; On the other hand, we will improve the social security system, gradually weaken the guarantee function of land, reduce the dependence of farmers on land and provide guarantee for the old-age care and unemployment of farmers.

Retaining Other Rights and Interests of Peasants as Members of the Collective Economic Organization. For the peasants who are willing to withdraw from the operation, but do not wish to settle down in the city, their right of the members of the collective economic organization of the village, the right to use the land and the right of villagers' autonomy are retained,which will not only alleviates the farmers' concerns about the housing problem after the contract, but also gives the farmers more choices, reducing the opportunity cost of the farmers' retreat.

\section{Acknowledgements}

National social science fund project "China interregional agricultural implicit carbon emission compensation mechanism and emission reduction path" (Number: 16CJL035).

\section{References}

[1] Wang Lishuang, Wang Chunping, Sun Zhanxiang. Study on the Impact of Farmers' Differentiation on the Withdrawal Intention of Rural Contracted Management Rights[J]. China Land Science, 2015(09):155-159.

[2] Han Lida, Han Dong. A Paid-off Study of Rural Land Contracting Management Rights from the Perspective of Marketization: Taking Chengdu as an Example[J]. Academic Journal of Zhongzhou, 2016(04):43-48. 